\title{
Gyula BÁNDI* \\ Interests of Future Generations, Environmental Protection and the Fundamental Law
}

\begin{abstract}
The Fundamental Law of Hungary has a special focus on sustainable development, the protection of the interests of future generations and the common heritage of the nation. The ombudsman for future generation is a special and unique institution, responsible for the safeguard of these issues. The primary mission of the ombudsman is to remind the state, including all the state organs and levels, of this task and responsibility, also to propose legislation and to examine individual complaints. In this article we provide a breif overview of those part of the Fundamental Law, which are well-equipped by the decisions of the Constitutional Court. Among others is is clear from the above cases, that everyone has a three-fold obligation towards the interest of the future generation: conservation of options, conservation of quality, and conservation of access. These are supported by the principle of non-derogation and also by the wide interpretation of precautionary principle, in connection with the fundamental right to the environment.
\end{abstract}

Keywords: interests of future generations, right to environment, common heritage of the nation, ombudsman for future generations, non-derogation/non-regression principle

\section{The objective}

The Conference at Miskolc, on 14th February 2020 was focused on a potential? review of the Fundamental Law of Hungary. Although the review is not a close reality, there is no explicit political or legislative will today, it is still worth discussing the idea itself, by exploring questions such as: is it necessary, are there any current trends, is there any use of changes, and so forth. Hence, instead of being a 'drafting exercise', the conference actually was tailored to prepare the coming $10^{\text {th }}$ anniversary of the Fundamental Law. The direct focus was agrarian and environmental law, both being significant in Hungary. From among the two subject matters, my interest is dedicated to environmental law, both as a professor, and also as the Ombudsman for Future Generations. As a professor, the constitutional provisions serve as the groundwork for any further studies beyond doubt. As an ombudsman, the provisions of the Fundamental Law - in my specific field mostly in connection with the interests of future generations and also with environmental rights - might be taken as flesh and blood of my activity, serving as the basis of our everyday practice.

Gyula Bándi: Interests of Future Generations, Environmental Protection and the Fundamental Law. Journal of Agricultural and Environmental Law ISSN 1788-6171, 2020 Vol. XV No. 29 pp. 7-22, https://doi.org/10.21029/JAEL.2020.29.7

* Ombudsman for Future Generations, DSc, PhD, Dr. habil., full professor, Faculty of Law and Political Sciences, Pázmány Péter Catholic University, e-mail: bandi.gyula@jak.ppke.hu. 
It is important to note that not only the precise provisions of the legal text are crucial for us, but also the interpretation of the legislative stipulations, more precisely the means and methods of how to translate the relatively brief paragraphs and articles into cases, applying them routinely in our practice. We believe and demonstrate that the Fundamental Law, being at the pinnacle of the Hungarian legal system, is undoubtedly a living organism, providing us guidance in the different fields of law. The provisions of the different parts of the Fundamental Law are actual legal requirements, applicable in different real life situations.

Probably the most interesting and by far the most significant element of recent development of the Hungarian legal system is the new constitution (adopted 25th April 2011), labelled as the 'Fundamental Law'. This - even the designation itself - indicates the conceptual change of the Hungarian legal and political system and wishes to suggest the real 'system change', encompassing - among others - many more environmental references and many more positive theoretical foundations for the interest of the environment and future generations than ever before.

\section{Ombudsman for Future Generations}

As a point of departure - supposing that the good reader may not necessarily be aware of it in details - we should learn something about the short history of this institution. In 2007 the attention of European and worldwide environmentalists turned towards Hungary, due to the enactment of the institution of the Parliamentary Commissioner (Ombudsman) for Future Generations, being the third specific individual commissioner next to the general commissioner (the two other specific commissioners at this time were: one responsible for minority rights and one for data protection). ${ }^{1}$ This parliamentary institution could receive special privileges and was regarded by many as an instrument for the advancement of sustainability.

The drafters of the new constitution (Fundamental Law) had a somewhat different concept related to the parliamentary protection of human rights, namely those opinions prevailed which did not agree with the relatively strong separate and individual ombudsmen system - altogether four independent institutions -, thus the concept to have one general ombudsman's office with deputies proved to be the preference. This is the current Commissioner for Fundamental Rights, having two deputies, who are also elected by the Parliament, but subordinated to the general ombudsman - one for minority rights and one for future generations. Consequently, the earlier separate Parliamentary Commissioner for Future Generations lost some of its independence only after three and half years. We should also note that the specific commissioner responsible for data protection is not a part of the system of parliamentary commissioners any longer, but a new authority for data protection was established instead. The current mandate of the ombudsmen system is regulated in detail by the Fundamental Law. ${ }^{2}$

\footnotetext{
${ }^{1}$ For some details, see among others: Majtényi 2008, 17-28. or Fodor 2008, 47-52.

2 Article 30 (1) The Commissioner of Fundamental Rights shall protect fundamental rights and shall act at the request of any person. (2) The Commissioner of Fundamental Rights shall examine or cause to examine any abuses of fundamental rights of which he or she becomes
} 
Consequently, today the Ombudsman for Future Generations (hereinafter the FG Ombudsman) is a Deputy to the Commissioner for Fundamental Rights. The FG Ombudsman is entrusted with a number of special powers, provided under the Ombudsman $\mathrm{Act}^{3}$ to foster the interests and needs of future generations and is accountable only to the Parliament. Its constitutional mandate has three main pillars (the details are discussed next): (a) the human right to a healthy environment (Art. XXI), (b) the right to physical and mental health, within which environmental protection is an instrument (Art.XX), (c) and finally a novel provision under Article P) enshrined in the Fundamental Law since 2011 stipulating the 'common heritage of the nation'.

This mandate includes the right to examine and comment on national and local legislative actions; to monitor policy developments and legislative proposals to ensure that they do not pose a severe or irreversible threat to the environment, thus causing possible harm to the interests of future generations; and to raise the attention of all stakeholders including the general public when the interests of future generations are at jeopardy. The FG Ombudsman can also prepare its own legislative proposals ${ }^{4}$ and publish non-binding recommendations or ombudsman opinions to ensure that the direct link between the nation's common heritage and the fundamental rights of all generations (including future generation) are respected.

The FG Ombudsman may initiate and/or participate in investigations upon complaints or ex officio which conclude with reports containing recommendations to any public authority including the Government. He can propose the Commissioner to turn to the Constitutional Court or the Curia (Supreme Court) of Hungary in cases where there is a strong belief that a national or local piece of legislation is in violation of the Fundamental Law. Also, the Ombudsman may initiate intervention in public

aware of and shall propose general or specific measures for their remedy. (3) The Commissioner of Fundamental Rights and his or her deputies shall be elected for six years by a two-thirds vote of the Members of Parliament. The deputies shall defend the interests of future generations and the rights of nationalities living in Hungary.

3 Act CXI of 2011 on the Commissioner for Fundamental Rights: Article 3 (1) The Deputy Commissioner for Fundamental Rights responsible for the protection of the interests of future generations shall monitor the enforcement of the interests of future generations, and (a) shall regularly inform the Commissioner for Fundamental Rights, the institutions concerned and the public of his/her experience regarding the enforcement of the interests of future generations, (b) shall draw the attention of the Commissioner for Fundamental Rights, the institutions concerned and the public to the danger of infringement of rights affecting a larger group of natural persons, the future generations in particular, (c) may propose that the Commissioner for Fundamental Rights institute proceedings ex officio, (d) shall participate in the inquiries of the Commissioner for Fundamental Rights, (e) may propose that the Commissioner for Fundamental Rights turn to the Constitutional Court, (f) shall monitor the implementation of the sustainable development strategy adopted by the Parliament, (g) may propose the adoption, amendment of legislation on the rights of future generations, and (h) shall promote, through his/her international activities, the presentation of the merits of domestic institutions related to the interests of future generations. One may find the English translation at our website: Office of the Commissioner for Fundamental Rights 2020.

${ }^{4}$ After two years of careful consultation a comprehensive proposal on environmental liability has been issued, see: Jövő Nemzedékek Érdekeinek Védelmét Ellátó Biztoshelyettes 2019. 
administrative court cases regarding environmental protection, by proposing it to the Commissioner. In the daily work, lawyers and environmental policy experts of the FG Ombudsman's secretariat heavily rely on the decisions and constitutional interpretations of the Constitutional Court and the Curia.

It might be the best to summarize the essence of our mission, using parts of the foreword from the 2018 English language annual report of the Office of the Commissioner (as the report of 2019 is still under translation): 5 "Protecting the rights of future generations is one of the key tenets of sustainable development. The idea of sustainability has an ecologic content, in its key focus is the integration that gives high priority to the environmental conditions of the present and future generations in every decision-making process. It is this kind of sustainability that the Deputy-Commissioner for Fundamental Rights, Ombudsman for Future Generations and his colleagues have been working for in the past ten years. The message of the UN Human Rights Committee of October 2018 clarifies the correlations between the rights of future generations and traditional human rights, this is why we think that it is a great stride forward that when Hungary presented a Voluntary National Review on the implementation of Sustainable Development Goals at the UN's High-level Political Forum in July 2018, the summary prepared by the Hungarian Ombudsman for Future Generations was specifically discussed. Even now, there are very few institutions in the world whose mission is similar to the mandate of the Hungarian Ombudsman for Future Generations. Although the protection of the environment or the future generations is mentioned in many constitutions in the world, there are very few of them in which all this is consistently enforced from the preambles through the general provisions to the fundamental rights.

The primary mission of the Ombudsman for Future Generations is to remind the state, including all the state organs and levels, of this task and responsibility. The elaboration of a modern and efficient system of responsibility is a kind of job in which everyone participates, from the civil society organizations through the professional-economic advocacy groups to the state. The operation of this unique system of cooperation, the harmonization of interests and viewpoints is such a challenge which can be best met by an independent institution like the Ombudsman for Future Generations."

The most recent decision of the Constitutional Court, ${ }^{6}$ related to the protection of forest of nature conservation areas testifies: "[35] ... the Constitutional Court shows that according to Par. (2) of Art. 1 of the Ombudsman Act the Commissioner for Fundamental Rights should provide special attention to the protection of the interests of those values manifested in Art P) of the Fundamental Law, and the deputy commissioner responsible for the interests of future generations among others might propose that the commissioner should turn to the Constitutional Court. Therefore, the Commissioner for Fundamental Rights together with the deputy commissioner responsible for the interests of future generations plays a crucial institutional role in the protection of those natural and cultural assets which belong to the common heritage of the nation. Par. (1) of Art P) stipulates that the natural and cultural values shall be

\footnotetext{
${ }^{5}$ Office of the Commissioner for Fundamental Rights 2019, 52-53.

${ }^{6}$ Constitutional Court Decision no.14/2020 (VII.6.).
} 
protected on their own, respectively orders that these should be preserved for future generations which does not have legal personhood, if necessary even against the (actual economic) interest of current generations." This mandate is a challenge for us that we are certainly honoured to face.

Applying the Fundamental Law in our daily practice is the major characteristic of handling citizen complaints. According to Art. 18 of the Ombudsman Act a citizen may file a complaint if he/she feels that the public administration in its broadest sense or a public service provider "infringes a fundamental right of the person submitting the petition or presents an imminent danger thereto (...), provided that this person has exhausted the available administrative legal remedies, not including the judicial review of an administrative decision, or that no legal remedy is available to him/her." Besides conducting investigations upon complaints received, the Commissioner for Fundamental Rights may also conduct ex officio proceedings, in cases when potential infringement affect the fundamental rights of larger groups of natural persons or when a comprehensive inquiry into the enforcement of a fundamental right is justifiable. These investigations - excluding those, where our office has no competence or where the complaint is manifestly unfounded etc. (see for the details Art. 20 of the Act) - are completed with a report, or in cases related to mandate of the FG Ombudsman, with a joint report, which contain a description of the facts uncovered, legal implications and future recommendations for authorities involved.

In all of the abovementioned reports or joint reports ${ }^{7}$ referencing the legal basis is an obligatory element, within which the human rights/fundamental rights relationship is the most important aspect, always on the basis of one or more article of the Fundamental Law. This reference does not simply imply an excerpt of the Law, but it is a comprehensive and detailed analysis instead, encompassing the relevant Constitutional Court decisions and the relevant previous Ombudsman practice. ${ }^{8}$

\section{Fundamental Law and the environment}

The Fundamental Law, the new constitution since 2011 (as it is definitely the constitution of the country) is divided into the following parts, each symbolized by different ways of numbering: (a) The preamble, or National Avowal, acting as a much longer preamble than ever before; (b) Groundwork or Foundation, covering several basic rules (official language, capital of Hungary, format of the state, major messages) and also some procedural elements related to legislation; (c) Freedom and Responsibility - in essence the human rights or fundamental rights part; and finally (d) The State, the major institutions of the state up to the budgetary or defence issues.

\footnotetext{
7 One may find them in Hungarian at: Alapvető Jogok Biztosának Hivatala 2020.

8 Usually 4-5 pages of the report go under the subtitle 'In connection with the affected fundamental rights and constitutional values'. As an example: a recent waste management case Alapvető Jogok Biztosának Hivatala 2019.
} 


\subsection{The preamble or National Avowal}

Contains fundamental environmental elements, embodied in a larger context. "We commit ourselves to promote and safeguard our heritage, our unique language, the Hungarian culture, the languages and cultures of nationalities living in Hungary, along with all man-made and natural assets of the Carpathian Basin. We bear responsibility for our descendants; therefore, we shall protect the living conditions of future generations by making prudent use of our material, intellectual and natural resources."

There are two major concepts presented in this paragraph, all are essential from the point of view of the environment: (a) National assets or national heritage, which cover not only assets within the boundaries of Hungary, but also in the whole Carpathian basin. A good example is the 'Pannon biogeographical-region's being a part of the biogeographical-region distribution of the Natura 2000 system since 2007. We may also refer to the concepts of the 'common heritage of mankind'10 or 'common concern of humanity'11 in international law as similar arguments. (b) The reference to future generations is a primary element, supported by the decisions of the Constitutional Court from the past three years. This goes along with the emphasis on different types of natural resources, which together may also be taken as constituents of sustainable development.

We should also mention human dignity, a third conceptual question, raised by the Preamble in a different paragraph: 'We hold that human existence is based on human dignity.' Human dignity may best be protected together with the natural environment and environmental protection in a wider context. One cannot separate human dignity from the fact that humanity is part of nature. Human dignity is strictly interrelated with the concept of future generations from the very beginning.

According to Article 1 of the EU Charter of Fundamental Rights:12 "Human dignity is inviolable. It must be respected and protected." The short explanation, provided for by the EU Fundamental Rights Agency $^{13}$ is clear in this respect: "The dignity of the human person is not only a fundamental right in itself but constitutes the real basis of fundamental rights." A clear and brief ethical summary is offered by the Venice Declaration: ${ }^{14}$ "Respect for creation stems from respect for human life and dignity. It is on the basis of our recognition that the world is created by God that we can discern an objective moral order within which to articulate a code of environmental ethics."

A final important reference to the equity for future generations, in line with the equity towards current generations, as being essential constituents of the constitutional provisions is stated as follows: "Our Fundamental Law shall be the basis of our legal order; it shall be an alliance among Hungarians of the past, present and future...."

\footnotetext{
${ }^{9}$ For details see: European Commission 2019.

10 One of the early explanations: White 1982.

11 See: Shelton 2009, 33-40.

12 Official Journal of the European Union C 303/17.

${ }^{13}$ European Union Agency for Fundamental Rights 2020.

${ }^{14}$ Venice Declaration, 2002.
} 


\subsection{Foundation}

Is the collection of the most important general or basic requirements and statements, such as Article B (1): 'Hungary shall be an independent, democratic state governed by the rule of law.' From the environmental or even more, future generations' point of view, we select below the most relevant articles.

Although with a significantly weaker connection to our portfolio, Par (1) of Art N) should also be mentioned: "Hungary shall observe the principle of balanced, transparent and sustainable budget management." Of course, this does not refer to sustainable development, but states that the budget should be sustainable, also meaning here: 'able to be maintained or continued'15 keeping in mind that 'a sustainable plan, method, or system is designed to continue at the same rate or level of activity without any problems."16

Article P) ${ }^{17}$ and more precisely, Par. (1) of the Article is a very complex summary of common heritage, using the definition in a broad context and also referring to future generations, but in a much more detailed and elaborate way: "All natural resources, especially arable land, forests and drinking water supplies, biodiversity - in particular native plant and animal species - and cultural assets shall form part of the nation's common heritage, and the State and every person shall be obliged to protect, sustain and preserve them for future generations." This article provides a list of elements of common heritage, without being exhaustive, thus allowing the extension of the list. The Constitutional Court is also clear in this respect: „,35] Par. (1) of Art. P) of the Fundamental Law designates the subject of environmental protection in a nonexhaustive list (see the 'especially' expression)."18

Still, the truly crucial question here is the focus on obligations and not only the mere reference to rights, as will later be discussed. Some details are highlighted below in connection with decisions of the Constitutional Court. This special emphasis on obligations or duties is very similar to the explanatory memorandum of the relevant document of the Parliamentary Assembly of the Council of Europe, which reads: ${ }^{19}$ "12. At present, we are witnessing what could be called a fourth generation of fundamental rights, or a generation of rights and duties for the society of the future. Society as a whole and each individual in particular must pass on a healthy and viable environment to future generations. That is quite simply the principle of solidarity between generations."

\footnotetext{
15 According to the Cambridge Dictionary.

16 According to Collins Dictionary.

17 See: Sulyok 2019.

${ }_{18}$ Constitutional Court Decision no. 28/2017. (X.25.).

${ }^{19}$ Report | Doc. 12003 | 11 September 2009 Drafting an additional protocol to the European Convention on Human Rights concerning the right to a healthy environment, B. Explanatory memorandum by Mr José Mendes Bota, Rapporteur, Parliamentary Assembly 2009.
} 
In comparison with Par (1) of Art. P), Par (2) of the same article is far from being a similar fundamental and creative provision ("(2) The limits and conditions for acquisition of ownership and for use of arable land and forests that are necessary for achieving the objectives referred to in paragraph (1), as well as the rules concerning the organisation of integrated agricultural production and concerning family farms and other agricultural holdings, shall be laid down in a cardinal Act.”). This paragraph does not have such a far-reaching theoretical objective as Par. (1) has, but is rather a simple answer to a contemporary political issue, which could and should easily be solved in a lower level legal regulation. It is nothing but a kind of regulatory authorization and does not have an interpretative benefit.

Article Q(1) is very similar to Article 3, Par. 5 of the Treaty of European Union $(\mathrm{TEU})^{20}$, combining international commitments and cooperation with sustainability: 'In order to create and maintain peace and security, and to achieve the sustainable development of mankind, Hungary shall strive for cooperation with every nation and state of the world.' A good example is the Voluntary National Review of Hungary related to the Sustainable Development Goals (SDGs) of the UN21 in 201822, within which the FG Ombudsman had a separate chapter, mostly focusing on the relationship of human rights and sustainable development. The Review, at its beginning, also refers to the Fundamental Law: "Sustainability is a core strategic principle, and as such is central to policy making in Hungary. The Government sets policies and regulations in order to carry out all the goals established in the Fundamental Law, international agreements, national legislation and strategies, and in connection with the SDGs."23

\section{3. 'Freedom and Responsibility'}

Is the human or fundamental rights chapter of the Fundamental Law, containing all the general rights. Here we only refer to those which may directly be taken as environmental rights or are closely related to them.

First, Art. II leads us back to the preamble: "Human dignity shall be inviolable. Every human being shall have the right to life and human dignity; the life of the foetus shall be protected from the moment of conception." Human dignity may thus be taken as a central focus of the Fundamental Law.

\footnotetext{
${ }^{20}$ Consolidated version of the Treaty on European Union, HL C 326., 26.10.2012, 13-390.: " 5 . In its relations with the wider world, the Union shall uphold and promote its values and interests and contribute to the protection of its citizens. It shall contribute to peace, security, the sustainable development of the Earth, solidarity and mutual respect among peoples, free and fair trade, eradication of poverty and the protection of human rights, in particular the rights of the child, as well as to the strict observance and the development of international law, including respect for the principles of the United Nations Charter."

21 The list of sustainable development goals and targets both in English and Hungarian may be found and downloaded: Világunk átalakítása 2015.

22 Voluntary National Review of Hungary on the Sustainable Development Goals of the 2030 Agenda 2018.

${ }^{23}$ Ibid. 4.
} 
Article VI Par (1) might also be mentioned, as it is closely correlated with the jurisprudence of European Convention on Human Rights (ECHR): 'Every person shall have the right to the protection of his or her private and family life, home, relations and good reputation.' I would like to remind the Reader of the extensive judicial practice of the European Court of Human Rights, one fundamental point of reference being Article 8 of the European Convention of Human Rights, beingthe right to private life and home. ${ }^{24}$ Fortunately, we do not have to use indirect references as the ECHR, since we have our specific environmental rights at constitutional level since 1989.

The wording of Article XIII, Par. (1) underlines again the individual responsibility or obligations, which shall also be taken as a valuable element of human rights chapters, and may serve as the basis - among others - of future liability provisions: 'Every person shall have the right to property and inheritance. Property shall entail social responsibility.'

There are two particular articles focusing on the right to environment mostly in line with the provisions of the previous Constitution. First Article 70/D (public health), and second Article 18 (right to a healthy environment) of the former Constitution is to be noted here. These roots are very important since these could serve as the basis for the practice of the Constitutional Court prior to the Fundamental Law, and the lack of substantial changes in these provisions legalized the continuity of interpretation after the adoption of the Law.

Article XX is somewhat relatively indirect, connecting environmental protection to public health so that environmental protection is taken as an instrument for preserving public health: "(1) Every person shall have the right to physical and mental health. (2) Hungary shall promote the exercise of the right set out in paragraph (1) by ensuring that its agriculture remains free from genetically modified organisms, by providing access to healthy food and drinking water, by managing industrial safety and healthcare, by supporting sports and regular physical exercise, and by ensuring environmental protection."

Some remarks in connection with Apr (2): while access to healthy drinking water ${ }^{25}$ echoes the new trends of environmental rights, underlined by World Water Forums and others, the reference to genetically modified organisms (GMOs) and agriculture does not necessarily fit into a constitutional chapter on human rights issues, mainly as there are no other similar messages to any other specific items. Also, we should not forget that the use of GMOs is highly dependent upon the future trends of the EU legislation. While today this provision may be realistic, in the future it might need to be reformulated in a different way.

\footnotetext{
${ }^{24}$ We do not go into the details of this question, but refer to several papers, such as the most recent summary of ECHR case-law may be downloaded at: European Court of Human Rights 2020 or from among the several papers, see, for example: Verschuuren 2014 or in Hungarian: Raisz 2011, 90-108 or a PhD dissertation: Hermann 2016.

25 There are several papers in the field of water legislation, such as: Szilágyi 2019, 182-197. or Szilágyi 2018.
} 
Unfortunately, the GMO-free zone is practically very insecure ${ }^{26}$. Somehow this is a naive reference to GMO-free agriculture which may be proclaimed but hard to manage.

Article XXI is the specific article on environmental rights, the first paragraph of which provided the major legal basis for interpretation for the Constitutional Court until recently: "(1) Hungary shall recognize and enforce the right of every person to a healthy environment. (2) Anyone who causes damage to the environment shall be obliged to restore it or to bear the costs of restoration, as provided for by an Act. (3) No polluting waste shall be brought into Hungary for the purpose of placement."

While Par (1) is the survival of the today 30 years old formula, having a substantial case practice at least by the Constitutional Court, the two new paragraphs are less practical. Par (2) is a narrow understanding of the polluter pays principle, the main fault of which is the missing reference to prevention and precaution. The principle should be interpreted in a complex mode. A good example of this is the document that was inspired by the OECD 20 years after the first recommendation: ${ }^{27}$ "The 'polluter pays' principle ... implies that in general it is for the polluter to meet the costs of pollution control and prevention measures, irrespective of whether those costs are incurred as a result of the imposition of some charge or pollution emission, or are debited through some other suitable economic mechanisms, or are in response to some direct regulation leading to some enforced reduction in pollution."

The preamble of the Environmental Liability Directive also refers to the complex understanding: "According to the 'polluter-pays' principle, an operator causing environmental damage or creating an imminent threat of such damage should, in principle, bear the cost of the necessary preventive or remedial measures." 28 But any other form of liability might also be taken as means of 'payment' - even criminal liability -, of the person found responsible.

$\operatorname{Par}(3)$ is an unfortunate reference to the transboundary movement of wastes, because of two reasons: first, similar to the case of polluter pays principle, it would be better placed only in the waste management act, as it really does not fit into a constitutional act; second, the wording, the definitions used here are far from being accurate from the point of view of waste management legal concepts. Neither 'placement ${ }^{29}$ ' is a proper definition, nor 'polluting waste.' This paragraph does not refer to disposal, or landfilling - which could have been mentioned here - but uses a definition that is not even present in the current Hungarian waste legislation.

\footnotetext{
${ }^{26}$ In terms of GMO studies see, for example: Tahyné Kovács 2018, 173-194 or Tahyné Kovács 2018, 72-87.

27 Note on the Implementation of Polluter Pays Principle (OECD, Paris, 1974) in McLoughlin \& Bellinger 1993, 146.

${ }^{28}$ Directive 2004/35/EC of the European Parliament and of the Council of 21 April 2004 on environmental liability with regard to the prevention and remedying of environmental damage, (OJ L 143, 30.4.2004, 56.), preamble (18).

${ }^{29}$ In some English translations of the Fundamental Law the term 'disposal' is used, but the Hungarian definition does not correspond to it.
} 
Consequently, the wording needs further clarification in the future in case anyone is willing to refer to it, but it would be even better to simply remove from the Fundamental Law.

\subsection{The State}

Finally, within the chapter on the state - beside our reference to the Commissioner for Fundamental Rights - there is one more provision which could also be connected with environmental protection. This article is a provision of the part on public finances, having some reference to the protection of resources and also to future generations. Par (1) Art 38 reads: "The property of the State and local governments shall be national assets. The management and protection of national assets shall aim to serve public interest, to satisfy common necessities and to safeguard natural resources, to take into consideration the needs of future generations..." This message fits properly into the mostly positive and innovative shift of the constitutional law, encompassing sustainable development and primarily the issue of future generations.

Still there might be one element which needs further elaboration, namely what national asset means, mostly in connection with natural resources. The Constitutional Court in one of its recent decisions ${ }^{30}$ clearly refers to ecological services, or ecosystem services which offer values, products and services to mankind. They even list the four types of ecosystem services which are commonly used: provisioning services (eg. food, timber, etc.); regulating services (eg. plants cleaning air and filtering water, regulating climate, etc.); cultural services (where, amongst others, recreation belongs); and supporting services (eg. photosynthesis, the creation of soils, the water cycle). When we think about national assets or making decisions about investments, these should also be taken into consideration.

\section{The case-law of the Constitutional Court}

In many instances above, we could refer to the decisions of the Hungarian Constitutional Court which interpret provisions on the right to a healthy environment both of the earlier Constitution and of the current Fundamental Law. After the adoption of the Fundamental Law a major concern was how to use the past decisions under the current situation. Soon after the fourth amendment of the Fundamental Law, the Constitutional Court could find the way to interpret these provisions. The conclusion of the Court was: ${ }^{31}$ "[34] The possible employment of arguments from previous decisions shall be decided by the Constitutional Court on a case-by-case basis, looking at the context of the specific problem." Consequently, the Court itself argued for the continuity of constitutional interpretations.

In order to set the scene, we must underline that the Constitutional Court, while a bit hesitant in certain other issues, is relatively active in interpreting the cases in connection with the right to a healthy environment and is widening its approach to cover even more aspects than earlier.

\footnotetext{
${ }^{30}$ Constitutional Court Decision no. 28/2017. (X.25.).

${ }^{31}$ Constitutional Court Decision no. 13/2013. (VI.17.).
} 
There is no room here to look at the previous decisions ${ }^{32}$, but we should provide some recent examples, and a summary of the whole vision of the Constitutional Court decisions.

The first in the list is the decision (Constitutional Court Decision no. 28/2017. (X.25.)), connected with nature conservation, more specifically with Natura 2000 protection versus agricultural uses. Some new provisions of agricultural uses - according to the Court - limited the chances and effectiveness of nature conservation, while it did not prove to be a necessary condition or prerequisite in order to protect any other human right or constitutional value (principle of proportionality). The verdict declared that the legislator had made an omission which led to the lack of conformity with the Fundamental Law. Fortunately, the Court referenced some very important basic requirements, which could be used for any further legal arguments. They underlined the importance of biodiversity, the special use of Natura 2000 sites, referred to the common heritage of the nation - which is closely connected to the common heritage of mankind, - and emphasized the non-regression (or nonderogation) principle - being core issues of the Court decisions since the very first one. ${ }^{33}$ According to the Court, while environmental protection is everyone's obligation, the responsibility of the state is even greater, as the state shall also create the underlying legal conditions of effective environmental protection.

In this decision, the Court also interpreted the obligations towards future generations for the first time, as it has been articulated by Article. P) of the Fundamental Law. This encompasses a three-fold obligation: (1) conservation of options, (2) conservation of quality, and (3) conservation of access.

All the three shall be used in a way to protect the interest of future generations. In the given case it means that the purely economic vision in connection with the utilization of Natura 2000 sites may not be accepted. Finally, the Court clearly stated that the state, when making various decisions in connection with nature conservation, must keep in mind the precautionary principle and long-term thinking. The precautionary principle has been taken as part of the constitutional right to the environment.

A next judgment (Constitutional Court Decision no. 3223/2017. (IX.25.)), while rejecting the motion, widely interpreted the principle of non-derogation, which must apply to both the regulatory steps and the individual decision of the authorities. Also, it affirmed the requirement to carry out necessity assessment and proportionality test when making such decisions.

A third judgment - (Constitutional Court Decision no. 13/2018 (IX.4.)) - is based upon the constitutionality initiative of the President of the Republic, using to a large extent the arguments of the FG Ombudsman submitted to the Constitutional Court in an amicus brief. The main issue is water management, more specifically, the unlimited drilling and use of groundwater wells, down to the level of 80 metrers.

\footnotetext{
32 There are several analyses on these decisions, such as Fodor 2006 or Bándi 2019, 339-382.

${ }^{33}$ Constitutional Court Decision no. 28/1994. (V.20.).
} 
This judgment combines the references to future generations and right to a healthy environment with the questions of state property or even more with the question of national assets (Article. 38 of the Fundamental Law) - since water resources belong to this scope.

The non-regression principle is underlined again, as being based on the provisions of Fundamental Law, and it is combined with the precautionary principle, also distinctly referred to. When applying these principles the necessity-proportionality test shall be used, comparing the protection of the environment to the protection of various other human rights. As the proposed law aims to eliminate the permitting or notification requirements in case of the given wells without replacing this with any other guarantees, the Court could not accept this regression in the level of protection. We also should not forget - says the Court - that the protection of water resources is a strategic duty of the state. The legislator could not point to any other human rights of constitutional interests which might support the limitation of environmental rights.

Our final example points to another milestone decision by the Constitutional Court, for which the groundwork was started in 2018, when the FG Ombudsman reviewed the consequences of the amendment of the Forest Act. and proposed the Commissioner for Fundamental Rights to initiate a norm control by the Constitutional Court aimed at establishing the lack of conformity with the Fundamental Law at the end of the year. The Commissioner on the proposal of the FG Ombudsman requested the annulment of those provisions which on the one hand decreased the level of protection of protected natural areas, strictly protected natural areas, Natura 2000 areas, as well as the locally protected natural areas, while on the other hand, of those which introduced procedural rules which may bring about such a negative result. He pointed out that the Nature Protection Act ensures the protection of natural values for all the sectors, and the Forest Act may not reduce this level of protection. The goal of the forest managers is determined by the primary function of the forest, this is why the primary function of the forests in protected natural areas should be one of protective nature, as in this way, the economic function of the forest will not be applicable, or only to a limited extent. The amendment of the law prescribed the primary protective function only for the strictly protected natural areas, and not for those natural areas which are 'simply' protected, i.e. not for the majority of the forests. As a result of the amendment, the level of protection of the forests in Natura 2000 areas has also changed significantly, as it has considerably decreased the level of protection of protected species. The FG Ombudsman said that this amendment gave rise to special concerns, as it led to the subordination of nature protection goals in state-owned forests too, although the primary reason for the nationalization of the protected natural areas was always to attain nature protection goals, which should notbe overridden by profit-oriented private interests.

The Court - with some minor exceptions - agreed with the arguments and annulled several items from the forest act. ${ }^{34}$ Many of the previous arguments (non-regression etc.) have been repeated, and some new elements added. One of the new reasons has been that the state has a special responsibility towards future generations and should think about the natural and cultural assets as public trust.

${ }^{34}$ Constitutional Court Decision no. 14/2020. (VII.6.). 
Forests belong to the national heritage and this implies obligations to all. The natural and cultural assets have their intrinsic value of their own.

As demonstrated above, the case law of the Hungarian Constitutional Court focusing on environmental protection and the rights of future generations is dinamically evolving and the mandate of the FG Ombudsman can offer a useful tool in this process both by initiating constitutional reviews of certain acts or by offering professional legal arguments in amicus briefs.

Summing up the lessons of case-law of the Constitutional Court, mentioning only the most important items, provides the following conclusions: (a) the right to (a healthy) environment is a fundamental right, (b) this requires institutional protection on behalf of the state, (c) and the state has a paramount role, a primary obligation to be active in this field, while (d) the duty to preserve and protect is for everyone, (e) the non-derogation (non-regression or non-retrogression) principle might be taken as the basis of understanding, having material, institutional and procedural aspects, (f) when making decisions the principle of proportionality shall be applied, (g) the interests of future generations shall be protected via the obligation of the current generations, (h) it shall be based on the precautionary and prevention principles, consequently, (i) long-term thinking is a prerequisite, (j) the cultural and natural assets belong to the common heritage of the nation, together with ecosystem services, using the public trust doctrine. 
Gyula Bándi

Interests of Future Generations, Environmental Protection

and the Fundamental Law
Journal of Agricultural and

Environmental Law

$29 / 2020$

\section{Bibliography}

1. Alapvető Jogok Biztosának Hivatala (2019) Az alapvetô jogok biztosának és a jövő nemredékeke érdekeinek védelmét ellátó helyettesénak közös jelentése ar. AJB-385/2019. számú ügyben, in:

https://www.ajbh.hu/documents/10180/3190211/K\%C3\%B6z\%C3\%B6s+jele $\mathrm{nt} \% \mathrm{C} 3 \% \mathrm{~A} 9 \mathrm{~s}+$ hullad $\% \mathrm{C} 3 \% \mathrm{~A} 9 \mathrm{k}+$ elhelyez $\% \mathrm{C} 3 \% \mathrm{~A} 9 \mathrm{se}+\% \mathrm{C} 3 \% \mathrm{BC} g \mathrm{0} \% \mathrm{C} \% \mathrm{~A} 9$ be $\mathrm{n}+385 \_2019 / 2 \mathrm{bd} 49 \mathrm{~b} 12-8028-f b c 8-407 d-2 a b 4 d a 3$ fcead?version=1.0 [02.10.2020]

2. Alapvető Jogok Biztosának Hivatala (2020) Jelentések, indítványok, állásfoglalások, in https://www.ajbh.hu/hu/jelentesek-inditvanyok-allasfoglalasok [02.10.2020]

3. Bándi Gy (2019) Környezethez való jog, in: Schanda B, Balogh Zs, ed., Alkotmányjog - alapjogok, Pázmány Press, Budapest, 339-382.

4. European Commission (2019) The Pannonian Region, in:

https:// ec.europa.eu/environment/nature/natura2000/biogeog_regions/panno nian/index_en.htm [02.10.2020]

5. European Court of Human Rights (2020) Environment and the European Convention on Human Rights, in:

https://www.echr.coe.int/Documents/FS_Environment_ENG.pdf [02.10.2020]

6. European Union Agency for Fundamental Rights (2020) EU Charter of Fundamental Rights, in: https://fra.europa.eu/en/eu-charter/article/1-humandignity\#TabExplanations [02.10.2020]

7. Fodor L (2008) A jövő nemzedékek jogai, Fundamentum, 1/2008, pp. 47-52.

8. Fodor L (2006) Környezetvédelem az. Alkotmányban, Gondolat Kiadó, Debreceni Egyetem, Állam- és Jogtudományi Kar, Debrecen.

9. Hermann V (2016) Az egészséges környezethez való jog átfogó védelme az. Emberi Jogok Európai Biróságának gyakorlatában, PhD Thesis, University of Pécs, Pécs

10. Jövô Nemzedékek Érdekeinek Védelmét Ellátó Biztoshelyettes (2019) A jövő nemzedékele szószólójának jogalkotási kezdeményezése a környezeti felelösség hatékonyabb érvényesitése érdekében,

https://www.ajbh.hu/documents/10180/3157803/Jogalkot\%C3\%A1si_kezdem $\%$ C3\%A9nyez $\%$ C3\%A9s_k $\%$ C3\%B6rnyezeti_felel $\%$ C5 $\% 91$ ss $\%$ C3\%A9g/4821a 1da-bb6b-8659-e97f-66f8b679c17d [02.10.2020]

11. Majtényi B (2008) A jövő nemzedékek és a természeti tárgyak köztársasága?, Fundamentum, 1/2008, pp. 17-28.

12. McLoughlin J - Bellinger E G (1993) Environmental Pollution Control, International Environmental Law and Policy Series, Graham and Trotman/Martinus Nijhoff.

13. Office of the Commissioner for Fundamental Rights (2020) Act CXI of 2011 on the Commissioner for Fundamental Rights, in: http://www.ajbh.hu/en/web/ajbhen/act-cxi-of-2011 [02.10.2020]

14. Office of the Commissioner for Fundamental Rights (2019) Report 2018 on the Activities of the Commissioner for Fundamental Rights and his Deputies, in: http://www.ajbh.hu/documents/14315/2993057/Report+on+the+Activities+ of + the + Commissioner + for + Fundamental + Rights + and + his + Deputies $+2018 / \mathrm{e}$ f5f4ffa-ef99-8cf8-e4d3-47ebb39b1026?version=1.0 [02.10.2020] 
15. Parliamentary Assembly (2009) Drafting an additional protocol to the European Convention on Human Rights concerning the right to a bealthy environment, in: http://assembly.coe.int/nw/xml/XRef/Xref-XML2HTMLen.asp?fileid $=12279 \&$ lang $=\mathrm{EN}[02.10 .2020]$

16. Raisz A (2011) A környezetvédelem helye a nemzetközi jog rendszerében avagy nemzetközi környezetjog bírói szemmel, Miskolci Jogi Sžemle, 1/2011, pp. 90-108.

17. Shelton D (2009) Common Concern of Humanity, Iustum Aequum Salutare, 5(1), pp. 33-40.

18. Sulyok K (2019) A környezet védelme és az Alaptörvény P) cikke az Alkotmánybíróság gyakorlatában, Alkotmánybirósági Szemle

19. Szilágyi J E (2018) Viąszemléletü kormányzás - vípolitika - vízjog: kitekintéssel a vízgazdálkodásra és a víztudományra, Miskolci Egyetemi Kiadó, Miskolc

20. Szilágyi J E (2019) Water and Law - a summary of the results of a natural resource law research, Journal of Agricultural and Environmental Law, 14(27), pp. 182-197., https://doi.org/10.21029/JAEL.2019.27.182.

21. Tahyné K Á (2018) A jogi szabályozás szükségességét kiváltó tényezőkről a GMO-k kapcsán, Iustum Aequum Salutare, 16(2), pp. 173-194.

22. Tahyné K Á (2018) Gedanken zur verfassungsrechtlichen Interpretierung der gesetzlichen Regelung der GVOs in angesichts der Verhandlungen der neuen GVO Verordnung der EU und des TTIP (Transatlantic Trade and Investment Partnership), Journal of Agricultural and Environmental Law, 10(18), pp. 72-87.

23. Venice Declaration, 2002: Common Declaration on Environmental Ethics of John Paul II and the Ecumenical Patriarch His Holiness Bartholomew I, Venice, Monday, 10 June 2002

24. Verschuuren J (2014) Contribution of the Case Law of the European Court of Human Rights to Sustainable Development in Europe, in: Scholtz W, Verschuuren J, ed., Regional Integration and Sustainable Development in a Globalised World, Edward Elgar Publishers

25. Világunk átalakítása (2015) A fenntartható fejlódés 2030-ig megvalósitandó programja, in: https://jak.ppke.hu/uploads/collection/545/file/Vilagunk_atalakitasa.pdf [02.10.2020]

26. Voluntary National Review of Hungary on the Sustainable Development Goals of the 2030 Agenda (2018) Transformation towards sustainable and resilient societies, in: https://sustainabledevelopment.un.org/content/documents/20137Voluntary_N ational_Review_of_Hungary_v2.pdf [02.10.2020]

27. White M V (1982) The Common Heritage of Mankind: An Assessment, Case Western Reserve Journal of International Law, 14(3) 